\title{
Expression Profile of Bcl-2 in Malignant Skin Tumors
}

\author{
Authors: \\ Sheikh Imran Sayeed ${ }^{1}$, Shazia Handoo ${ }^{2}$, Nazia Manzoor Walvir ${ }^{1}$, Hilal Ahmad Wani ${ }^{3}$, \\ Rafiq Ahmad Pampori ${ }^{4}$, Qazi Danish ${ }^{3}$ \\ ${ }^{1}$ Department of Physiology, Govt. Medical College Srinagar \\ ${ }^{2}$ Haematology and Transfusion Medicine, Govt. Medical College Srinagar \\ ${ }^{3}$ Multidisciplinary Research Unit, Govt. Medical College Srinagar. \\ ${ }^{4}$ Dean, Govt. Medical College Srinagar \\ Corresponding author: \\ Dr. Qazi Danish \\ Research Scientist-II, Multidisciplinary Research Unit, Govt. Medical College Srinagar \\ Email: qazi.danish@gmail.com
}

\begin{abstract}
Skin is the largest organ in the body and is most commonly affected by neoplasms. In the United States only, approximately 1.2 million cases of nonmelanoma skin cancer and 80,000 cases of melanoma are diagnosed annually. A large number of families of genes that regulate apoptosis have been identified in both normal and malignant cells. There is loss of bcl-2 protein expression with increasing tumor progression. The present study was undertaken to determine the presence and possible role of bcl-2 in primary cutaneous malignancies using immunohistochemical technique and was carried in the Department of Pathology, Government Medical College, Srinagar. Fifty surgical specimens were obtained from the surgical pathology files of Department of Pathology. Imnunohistochemical study was performed. Out of the fifty cases included in the present study, only twenty one cases (42.00\%) were positive for bcl-2 oncoprotein while as twenty nine cases (58\%)-exhibited negativity. Basal cell carcinomas constituted $38.10 \%$ of the total positive cases, followed by Malignant Melanoma (28.57\%) where as Keratoacanthomas accounted for only $4.76 \%$ positive cases. Squamous cell carcinoma and Bowen's disease constituted $14.28 \%$ each to the positive cases.

Keywords: Skin cancer, Immunohistochemistry, Srinagar, bcl-2, Apoptosis, Basal cell carcinomas, Malignant Melanoma, Keratoacanthomas, Squamous cell carcinoma, Bowen's disease.
\end{abstract}

\section{INTRODUCTION}

Skin is the largest organ in the body and is most commonly affected by neoplasms. The study of skin tumors requires understanding of morphologic and molecular alterations, as well as the interactions between genetic and environmental factors. Basal cell carcinoma, squamous cell carcinoma, and malignant melanoma are the three most common malignant neoplasms that arise in the skin. Malignant skin lesions have become increasingly prevalent over the past several years. In the United States only, approximately 1.2 million cases of nonmelanoma skin cancer and 80,000 cases of melanoma are diagnosed annually ${ }^{(1)}$. 
Apoptosis is a deliberate and genetically controlled cellular response to specific developmental and environmental stimuli. A large number of families of genes that regulate apoptosis have been identified in both normal and malignant cells ${ }^{(2)}$. The bcl-2 gene was identified as a gene translocated in human follicular B-cell lymphomas carrying a characteristic $\mathrm{t}$ (14; 18)(q32; q21) which results in removal of bcl-2 from its normal controls and leads to increased transcription and over expression of bcl-2 protein which protects cells from apoptosis ${ }^{(2)}$ The bcl-2 family members come in two functional categories; those that inhibit apoptosis and those that promote apoptosis. The inhibitors include mammalian bcl-2, Bel-x, mcl-1, A1, ced-9, BHRF-1, LMW5; and the promoters include BAX, BAK, BIM,BAD ${ }^{(3)}$. The determining factor for cell viability is the ratio of the level of the death inhibiting bcl-2 family members relative to that of death promoting bcl-2 family members. A high level of bcl-2 relative to BAX promotes cell survival whereas an excess of BAX relative to bcl-2promotes cell death ${ }^{(3)}$. Thus, a very fine balance exists between proapoptotic and antiapoptotic bcl-2 family members which regulate the cell fate in response to many signaling pathways. Altered expression of these proteins may lead either to premature cell death or to inappropriate cell survival promoting neoplastic growth. bc1-2 protein was found in the neoplastic cells in almost all the follicular lymphomas, whereas no bcl-2 protein was detected in follicles affected by non-neoplastic processes or in normal lymphoid tissue ${ }^{(4)}$. Overexpression of bcl-2 has been found to block the apoptotic death of a proB-lymphocyte cell line ${ }^{(5)}$. bcl-2 protein expression in patients with keratinocytes may be related to tumorigenic proliferation possibly due to enhanced cell survival, but not when inflammatory proliferation of keratinocytes is present ${ }^{(6)}$. It seems likely that the decreased bcl-2 expression detected in melanomas may reflect one further step of tumor progression in melanocytic neoplasms ${ }^{(7)}$. There is loss of bcl-2 protein expression with increasing tumor progression ${ }^{(8)}$. The anti-apoptotic protein Bcl-2 has the ability to block the MPT, and can therefore block MPTdependent necrosis in addition to their wellestablished ability to inhibit apoptosis ${ }^{(9)}$. In the adult organism, bcl-2 expression is generally confined to cells that are rapidly dividing and differentiating such as basal keratinocytes of skin and basal enterocytes. Over expression of bcl-2 protein has been observed in about $25 \%$ of high grade non-Hodgkin's lymphomas, malignant skin tumors, as well in solid tumors such as carcinomas of the lung, prostate, nasopharynx, stomach and colon ${ }^{(4)}$. In view of this, the present study was undertaken to determine the presence and possible role of bcl-2 in primary cutaneous malignancies using immunohistochemical technique.

\section{MATERIALS AND METHODS}

The present study was carried in the Department of Pathology, Government Medical College, Srinagar. Fifty surgical specimens were obtained from the surgical pathology files of Department of Pathology. The specimens consisted of twenty four Squamous cell carcinomas, ten Basal cell carcinomas and six malignant melanomas. Five cases each of Keratoacanthoma and Bowen's disease were also included in the present study. The original diagnosis was rendered on routine sections stained with hematoxylin-eosin, using the standard diagnostic criterion for each malignancy. All the cases were reviewed for diagnostic accuracy by a pathologist prior to inclusion in the study. The tissue sections were prepared from formalin fixed, paraffin embedded samples. Imnunohistochemical study was performed on 4$5 \mu \mathrm{m}$ serial tissue sections mounted on poly-lysine coated slides using the standard Avidin-BiotinPeroxidase complex technique. The paraffin sections were deparaffinized by placing them through three 5 minute changes of xylene. Deparaffinized sections were then hydrated with graded ethanol using three changes, 5 minutes each. Following deparaffinization and hydration, the sections were treated with $0.3 \%$ hydrogen 
peroxide in methanol for 30 minutes to quench endogenous peroxidase activity. The peroxidase block was discarded and three washes of phosphate buffer saline (PBS) were given. To optimize bcl-2 detection, the sections were placed in a thermo-resistant box in citrate buffer and exposed for 10 minutes to microwave fixation at 750 Watts to increase immunoreactivity. The slides were then kept at room temperature for cooling. After antigen retrieval, three washes of phosphate buffer saline were given for 5 minutes each. Non-specific protein binding was blocked with 30 minutes exposure to freshly prepared 5\% milk block in working PBS buffer. Subsequently three washes of PBS were given to make sure that all the milk had been completely removed from the slides. Once the sections were rinsed in distilled water and PBS, the slides were cleaned and incubated over night at $4^{\circ} \mathrm{C}$ with a primary monoclonal antibody bcl-2 in a moist chamber. Three washes of PBS were given for 5 minutes each before incubating the sections with secondary biotinylated rabbit anti-mouse immunoglobulin for 40 minutes. After rinsing, the sections were incubated for 40 minutes with streptavidin conjugated with horse-raddish Peroxidase. Then the slides were rinsed with PBS. Diaminobenzidine served as a chromogen substrate. The sections were then kept in distilled water and counter stained with Harris hematoxylin eosin for 10 seconds to 2 minutes, dehydrated in alcohol, cleared in xylene, cover slipped and viewed under light microscope.

\section{CONTROLS}

Special controls were run in order to test the protocols and for the specificity of the antibodies being used. Positive control was used to test for the protocol or procedure followed. Specimens used as positive controls consisted of reactive lymphoid hyperplastic tissue sections. Basal keratinocytes and scattered lymphocytes within dermal inflammatory infiltrates, both of which normally express bcl-2, served as positive internal controls. Negative control was used to test for the specificity of the antibody involved. Additional sections running in parallel but with the omission of primary antibody served as a negative control. Evaluation of bcl-2 staining:

The expression of bcl-2 protein was identified as diffuse golden-yellow cytoplasmic staining (sites of mitochondria). The positive cells were scored in several randomly selected fields at $\mathrm{x} 400$ magnifications. The percentage of positive cells was classified as per the guidelines of

American society of Dermatopathologists (1998) and is as follows:

$(+++$ : strongly positive) more than $50 \%$ of the total cells were stained against bcl-2 antibody in the cytoplasm;

$(++$ : moderately positive) $25-50 \%$ of the total cells were stained;

( - : negative) less than $25 \%$ of the total cells were stained.

\section{OBSERVATIONS}

The clinical data of the cases included in the study as obtained from the archival files of the department are given in table's I \& II. A total of twenty four cases (48\%) of Squamous cell carcinomas comprised of fifteen females $(62.5 \%)$ and nine males $(37.5 \%)$ with mean age of $75 \pm$ 5.4 (mean $\pm \mathrm{SD}$ ). The common presentation of Squamous cell carcinomas was a non-healing ulcer, a mass, or an ulcerated mass. The usual sites of occurrence were thighs, legs and lower abdomen. These are also common sites for "erythema ab agnae" which is caused by chronic irritation by heat due to use of kangri (a coal filled earthen pot) by native Kashmiri population to keep themselves warm during extreme climatic conditions in winter. Majority $(80 \%)$ of the squamous cell carcinoma samples included in the study were well differentiated, low grade keratinizing tumors. Ten cases $(20 \%)$ of Basal cell carcinoma included five females $(50 \%)$ and five males $(50 \%)$ with a mean age of $70 \pm 6.8$ (mean \pm $\mathrm{SD})$. The Basal cell carcinomas had presented as a nodule, ulcer or pigmented to ulcerated nodule. Four of the neoplasms occurred on the face, two 
on the upper arm and four on the trunk. None of the patients had the basal cell nevus syndrome. There were six cases (12\%) of Malignant Melanoma comprising of three males (50\%) and three females $(50 \%)$ of age $50 \pm 4.7$ (mean \pm SD). Malignant melanomas had presented as irregular deeply pigmented nodules and moles on trunk and extremities. There were five cases (10\%) of Bowen's disease and Keratoacanthoma each. Bowen's disease comprised of three females (60\%) and two males (40\%) of age $56 \pm 7.8$ (mean $\pm \mathrm{SD}$ ) where as Keratoacanthoma comprised of four females $(80 \%)$ and one male $(20 \%)$ of age
$60 \pm 5.5$ (mean \pm SD) with Keratoacanthoma. Bowen's disease had presented as an ulcer or a mass whereas Keratoacanthoma had presented as a mass or a nodule on thigh, abdomen or legs.

The statistical analysis of the data was done by using Chi-Square test ( $\chi 2$ - test) and Fisher's exact test. These tests were two sided and were referenced for $\mathrm{p}$-values for their significance. Any $\mathrm{p}$-value less than 0.05 i.e. $(\mathrm{p}<0.05)$ was taken to be statistically significant. The analysis was done by using Statistical package for social sciences (SPSS version 10.0) Chicago, U.S.A for windows 2000.

Table-I: Clinical details of the patients with squamous cell carcinoma

\begin{tabular}{|l|l|l|l|l|}
\hline $\begin{array}{l}\text { Case } \\
\text { no. }\end{array}$ & $\underline{\text { Age }}$ & $\underline{\text { Sex }}$ & $\begin{array}{l}\text { Presenting } \\
\text { symptom }\end{array}$ & $\underline{\text { Location }}$ \\
\hline 1. & 65 & F & Mass & Right Leg \\
\hline 2. & 68 & M & Ulcerated Mass & Thigh \\
\hline 3. & 82 & F & (NHU) & Thigh \\
\hline 4. & 65 & M & NHU & Lower Abdomen \\
\hline 5. & 80 & M & NHU & Lower Abdomen \\
\hline 6. & 75 & F & Mass & Right Leg \\
\hline 7. & 72 & M & Mass & Thigh \\
\hline 8. & 80 & F & Ulcerated Mass & Thigh \\
\hline 9. & 80 & F & Mass & Left Leg \\
\hline 10. & 65 & M & Mass & Right Leg \\
\hline 11. & 60 & F & NHU & Lower Abdomen \\
\hline 12. & 70 & F & NHU & Upper Abdomen \\
\hline 13. & 68 & M & NHU & Dorsum of Foot \\
\hline 14. & 80 & F & Mass & Thigh \\
\hline 15. & 76 & F & Ulcerated Mass & Thigh \\
\hline 16. & 74 & M & Mass & Lower Abdomen \\
\hline 17. & 78 & M & Mass & Left Leg \\
\hline 18. & 85 & F & Mass & Right Leg \\
\hline 19. & 84 & F & NHU & Lower Abdomen \\
\hline 20. & 86 & F & NHU & Dorsum of Foot \\
\hline 21. & 88 & M & Ulcerated Mass & Lower Abdomen \\
\hline 22. & 72 & F & Ulcerated Mass & Thigh \\
\hline 23. & 78 & F & NHU & Left Leg \\
\hline 24. & 74 & F & NHU & Right Leg \\
\hline & & & & \\
\hline
\end{tabular}

NHU: Non Healing Ulcer 
Table-II: Clinical details of the patients with squamous cell carcinoma

\begin{tabular}{|c|c|c|c|c|}
\hline Case no. & $\underline{\text { Age }}$ & $\underline{\operatorname{Sex}}$ & $\underline{\text { Presenting symptom }}$ & $\underline{\text { Location }}$ \\
\hline \multicolumn{5}{|c|}{ Basal Cell Carcinoma } \\
\hline 1 & 66 & $\mathrm{M}$ & Nodule & Face \\
\hline 2 & 56 & $\mathrm{M}$ & Pigmented Nodule & Face \\
\hline 3 & 65 & $\mathrm{~F}$ & Ulcerated Nodule & Hand \\
\hline 4 & 64 & $\mathrm{~F}$ & Nodule & Chest \\
\hline 5 & 62 & $\mathrm{M}$ & Ulcerated Nodule & Hand \\
\hline 6 & 68 & $\mathrm{~F}$ & Nodule & Hand \\
\hline 7 & 72 & $\mathrm{M}$ & Nodule & Face \\
\hline 8 & 70 & $\mathrm{~F}$ & Ulcer & Face \\
\hline 9 & 75 & $\mathrm{~F}$ & Ulcer & Face \\
\hline 10 & 76 & $\mathrm{M}$ & Nodule & Face \\
\hline \multicolumn{5}{|c|}{ Malignant Melanomas } \\
\hline 1 & 53 & $\mathrm{M}$ & Mole & Right Leg \\
\hline 2 & 56 & $\mathrm{M}$ & Pigmented Mole & Left Leg \\
\hline 3 & 48 & $\mathrm{~F}$ & Discharging Mole & Back \\
\hline 4 & 40 & $\mathrm{~F}$ & Mole & Back \\
\hline 5 & 55 & $\mathrm{M}$ & $\begin{array}{l}\text { Irregular Pigmented } \\
\text { Mole }\end{array}$ & Back \\
\hline 6 & 58 & $\mathrm{~F}$ & Mole & Left Leg \\
\hline \multicolumn{5}{|c|}{ Bowen's Disease } \\
\hline$\frac{1}{2}$ & & $\mathrm{M}$ & Mass & Thigh \\
\hline 2 & & $\mathrm{~F}$ & Mass & Abdomen \\
\hline 3 & & $\mathrm{M}$ & Ulcer & Right Leg \\
\hline \multirow{2}{*}{$\begin{array}{l}4 \\
\end{array}$} & & $\mathrm{~F}$ & Ulcer & Thigh \\
\hline & & $\mathrm{F}$ & Mass & Abdomen \\
\hline \multicolumn{5}{|c|}{ Keratoacanthoma } \\
\hline 1 & & $\mathrm{~F}$ & Mass & Thigh \\
\hline \multirow{2}{*}{$\frac{2}{3}$} & & $\mathrm{~F}$ & Nodule & Abdomen \\
\hline & & $\mathrm{M}$ & Mass & Left Leg \\
\hline \multirow{2}{*}{$\begin{array}{l}4 \\
5\end{array}$} & & $\mathrm{~F}$ & Ulcerating Nodule & Abdomen \\
\hline & & $\mathrm{F}$ & Nodule & Thigh \\
\hline
\end{tabular}


Table-III: Percentage Positivity of Bcl-2 expression in the Studied Cases

\begin{tabular}{|l|l|l|l|l|l|l|}
\hline $\begin{array}{l}\text { S.N } \\
\text { o }\end{array}$ & $\begin{array}{l}\text { Sample } \\
\text { Specimen }\end{array}$ & $\begin{array}{l}\text { Total } \\
\text { cases }\end{array}$ & $\begin{array}{l}\text { Positive } \\
\text { Cases }\end{array}$ & $\begin{array}{l}\text { Negative } \\
\text { cases }\end{array}$ & $\begin{array}{l}\text { \%age } \\
\text { Positivity }\end{array}$ & p-value \\
\hline 1 & $\begin{array}{l}\text { Squamous cell } \\
\text { carcinoma }\end{array}$ & 24 & 3 & 21 & $12.5 \%$ & 0.000 \\
\hline 2 & $\begin{array}{l}\text { Basal cell } \\
\text { carcinoma }\end{array}$ & 10 & 8 & 2 & $80 \%$ & 0.006 \\
\hline 3 & $\begin{array}{l}\text { Malignant } \\
\text { melanoma }\end{array}$ & 6 & 6 & 0 & $100 \%$ & 0.003 \\
\hline 4 & Bowen's disease & 5 & 3 & 2 & $60 \%$ & 0.638 \\
\hline 5 & $\begin{array}{l}\text { Keratoacanthom } \\
\text { a }\end{array}$ & 5 & 1 & 4 & $20 \%$ & 0.383 \\
\hline \multicolumn{2}{|l|}{ Overall total Cases } & 50 & 21 & 29 & $42.00 \%$ & \\
\hline
\end{tabular}

$\mathrm{P}<0.05=$ Significant

$P>0.05=$ Not Significant

Table-IV: Percentage of positive cells in positive cases

\begin{tabular}{|c|c|c|c|c|c|}
\hline S.No & Sample Specimen & $\begin{array}{l}\text { Strongly } \\
+ \text { ve }(+++)\end{array}$ & $\begin{array}{l}\text { Moderately } \\
+ \text { ve }(++)\end{array}$ & $\begin{array}{l}\text { Negative } \\
\text { cases }(\%)\end{array}$ & $\begin{array}{l}\text { Positive } \\
\text { Cases }(\%)\end{array}$ \\
\hline 1 & $\begin{array}{l}\text { Squamous cell } \\
\text { carcinoma }\end{array}$ & 2 & 1 & $21(72.40)$ & $3(14.28)$ \\
\hline 2 & $\begin{array}{l}\text { Basal cell } \\
\text { carcinoma }\end{array}$ & 5 & 3 & $2(6.90)$ & $8(38.10)$ \\
\hline 3 & $\begin{array}{l}\text { Malignant } \\
\text { melanoma }\end{array}$ & 4 & 2 & $0(0.00)$ & $6(28.57)$ \\
\hline 4 & Bowen's disease & 2 & 1 & $2(6.90)$ & $3(14.28)$ \\
\hline 5 & Keratoacanthoma & 1 & 0 & $4(13.8)$ & $1(4.76)$ \\
\hline \multicolumn{2}{|c|}{ Total Cases } & 14 & 7 & $29(58.00)$ & $21(42.00)$ \\
\hline
\end{tabular}

Table-V: Pattern of staining in the Positive Lesions studied

\begin{tabular}{|l|l|l|l|l|}
\hline S.No & Sample Specimen & Total Cases & Positive Cases & Staining Pattern \\
\hline 1 & $\begin{array}{l}\text { Squamous cell } \\
\text { carcinoma }\end{array}$ & 24 & 3 & $\begin{array}{l}\text { Focal staining to patchy } \\
\text { diffuse staining }\end{array}$ \\
\hline 2 & $\begin{array}{l}\text { Basal cell } \\
\text { carcinoma }\end{array}$ & 10 & 8 & Diffuse homogenous staining \\
\hline 3 & $\begin{array}{l}\text { Malignant } \\
\text { melanoma }\end{array}$ & 6 & 6 & Diffuse homogenous staining \\
\hline 4 & Bowen's disease & 5 & 3 & Focal to diffuse staining \\
\hline 5 & Keratoacanthoma & 5 & 1 & Focal staining \\
\hline
\end{tabular}




\section{JMSCR Vol||3||Issue||10||Page 7868-7878||October $\quad 2015$}

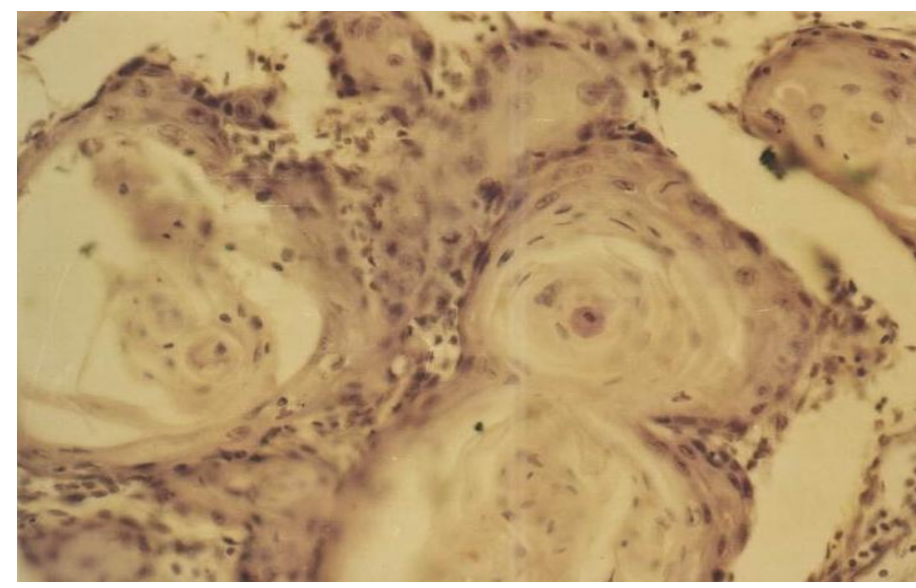

Fig. 1: Microphotograph showing bcl-2 negative case of squamous cell carcinoma (IHC $\times 400)$

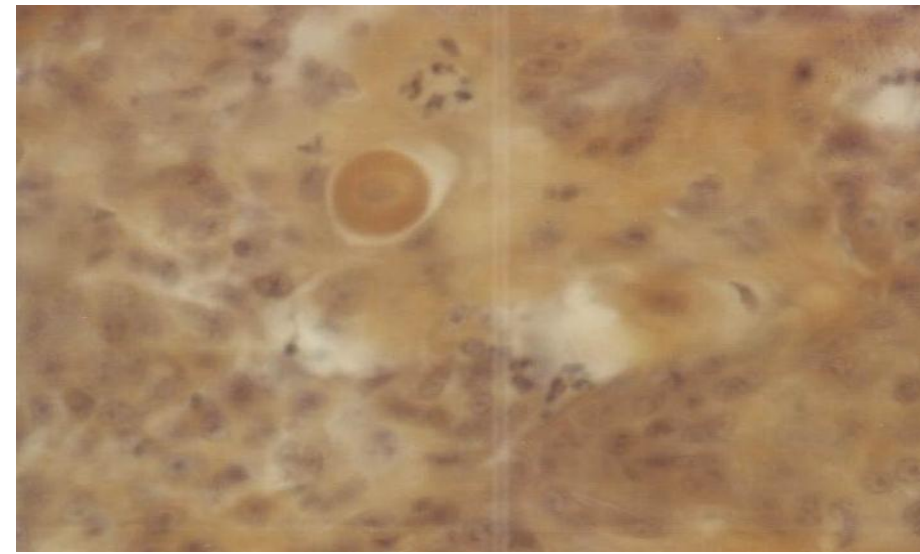

Fig. 2: Microphotograph showing bcl-2 positive case of squamous cell carcinoma $(\mathrm{IHC} \times 400)$

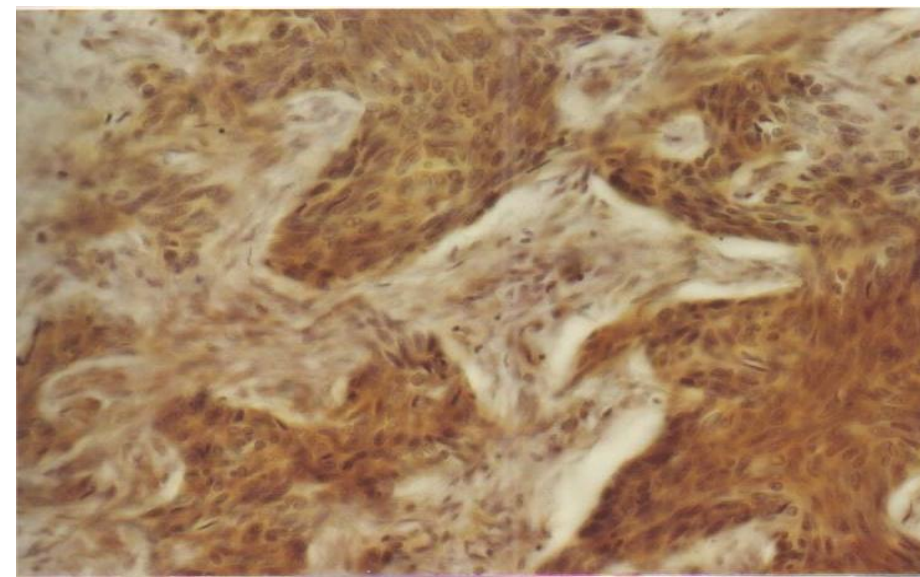

Fig. 3: Microphotograph showing bcl-2 positive case of basal cell carcinoma (IHC $\times 400)$

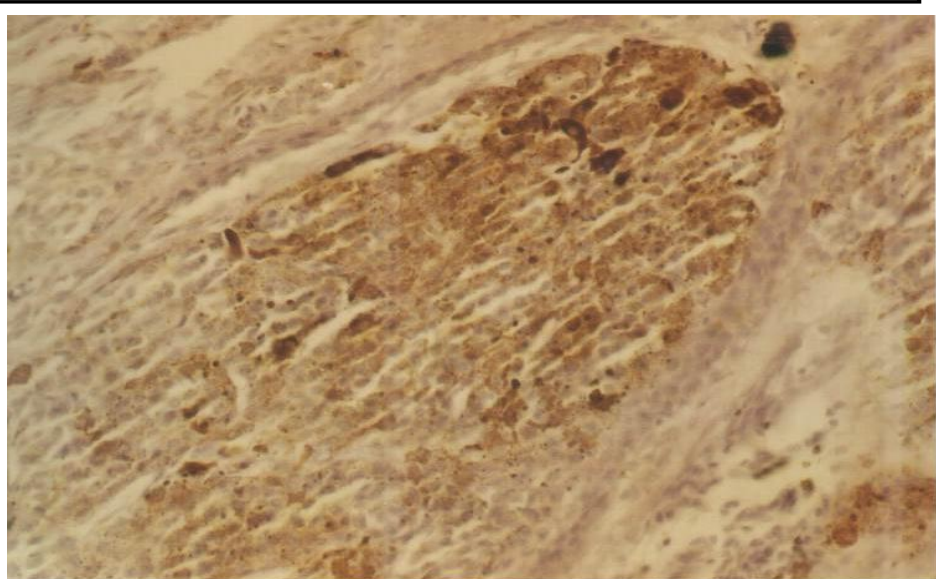

Fig. 4: Microphotograph showing bcl-2 positive case of malignant melanoma $(\mathrm{IHC} \times 400)$

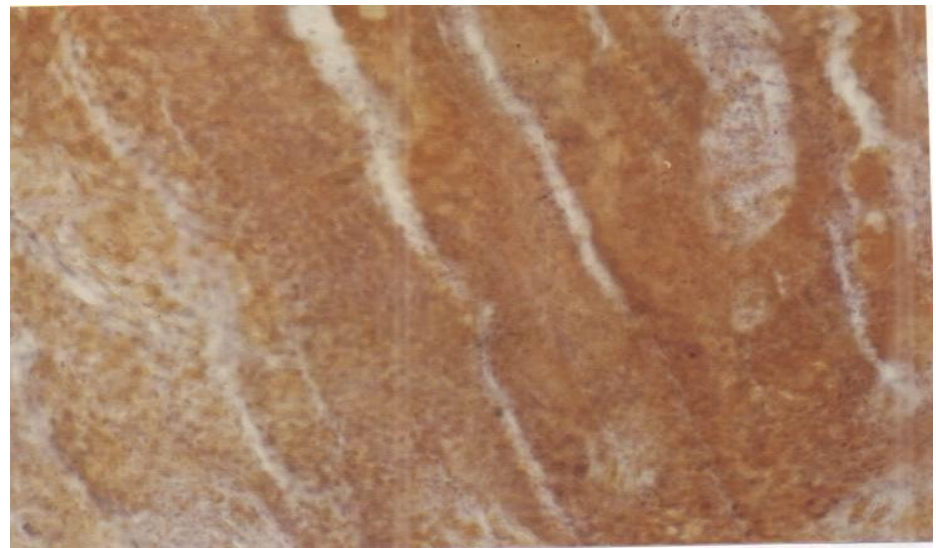

Fig. 5: Microphotograph showing bcl-2 positive case of Bowen's disease $(\mathrm{IHC} \times 400)$

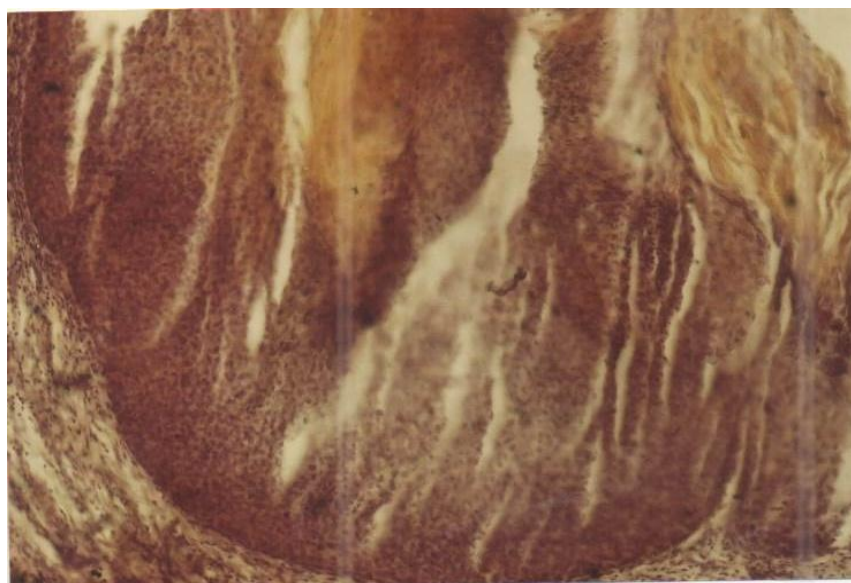

Fig. 6: Microphotograph showing bcl-2 positive case of Keratoacanthoma (IHC $\times 400)$ 


\section{RESULTS}

Out of the fifty cases included in the present study, only twenty one cases $(42.00 \%)$ were positive for bcl-2 oncoprotein while as twenty nine cases (58\%)-exhibited negativity. Basal cell carcinomas constituted $38.10 \%$ of the total positive cases, followed by Malignant Melanoma (28.57\%) where as Keratoacanthomas accounted for only $4.76 \%$ positive cases. Squamous cell carcinoma and Bowen's disease constituted $14.28 \%$ each to the positive cases. The immunohistochemical observations are given in tables III, IV and V.

Squamous cell carcinomas: The majority of squamous cell carcinoma were non reactive for the bcl-2 protein. Out of twenty four Squamous cell carcinoma samples (48\%) included in the study, only three (12.5\%) exhibited reactivity with anti-bcl-2. Two of these were strongly positive while one lesion was moderately positive. Two of these had patchy diffuse staining, and one stained only focally. A statistically significant difference ( $p$ value $<0.05$ ) was observed on comparing the percentage positivity of Squamous cell carcinomas $(12.50 \%)$ with overall percent positivity $(42.00 \%)$ of the cases studied.

Basal cell carcinoma: Basal cell carcinomas expressed high levels of bcl-2 protein. Out of ten basal cell carcinomas, eight stained positive, depicting a percentage positivity of $80 \%$. Five of them were strongly positive and three were moderately positive. Most Basal cell carcinomas demonstrated strong diffuse homogenous cytoplasmic staining throughout the tumour lobes. Some small basaloid cells exhibited cytoplasmic staining with perinuclear enhancement. Frequently, the staining exhibited by the BCCs for bcl-2 was greatly increased when compared with the staining present along the layer of basal cell keratinocyte in the uninvolved adjacent skin. The percentage positivity of Basal cell carcinoma was very high $(80 \%)$ and on comparison with overall percentage positivity of the cases (42.00\%), statistically significant difference $(\mathrm{p}<0.05)$ was observed.
Malignant Melanomas: Diffuse intracytoplasmic immunopositivity for bcl-2 protein, sometimes with perinuclear accentuation of staining was observed in neoplastic cells in $100 \%$ of malignant melanomas (6/6): Out of six positive cases, four showed strong immunopositivity for bcl-2 protein whereas the remaining two lesions were moderately positive. No difference was observed in bcl-2 expression among lesions arising from different body areas. A statistically significant difference $(\mathrm{p}<0.05)$ was observed on comparing the individual percentage positivity of Malignant Melanomas $(100 \%)$ with the overall percentage positivity of the cases $(42.00 \%)$.

Bowen's Disease: Out of the 5 cases of Bowen's disease, three showed immunoreactivity with antibcl-2, depicting a percentage positivity of $60 \%$.The expression of bcl-2 protein was restricted to the involved lesions and surrounding normal tissue with keratinocytes were bcl-2 negative. Two of them were strongly positive and one was moderately positive. The pattern of staining for bcl-2 varied from focal to diffuse homogenous. The percentage positivity of Bowen's disease (60\%) when compared with overall percentage positivity of the cases $(42.00 \%)$, showed a statistically insignificant difference $(\mathrm{p}>0.05)$.

Keratoacanthoma: Eighty percent $(80 \%)$ of the samples were negative for the staining. Only one out of five cases (20\%) exhibited immunoreactivity for anti-bcl-2.The positive case stained at the basal and few suprabasal cells only. A statistically insignificant difference ( $p$ value $>0.05$ ) was observed on comparing the percentage positivity of Keratoacanthoma $(20.00 \%)$ with overall percent positivity $(42.00 \%)$ of the cases studied

\section{DISCUSSION}

Skin is the largest organ in the body and is constantly exposed to environmental hazards; as a consequence, the skin is the tissue most commonly affected by neoplasms. Malignant tumors can arise from cells of any layer of the 
skin-keratinocytes, basal cells, melanocytes, fibroblasts, histiocytes, endothelial cells, or adipocytes-as well as from cells such as lymphocytes, which normally transit through the skin ${ }^{(1)}$. Cutaneous metastases may also arise from other primary sites elsewhere. Accumulation of neoplastic cells may occur not only by the activation of oncogenes or inactivation of tumor suppressor genes but also by mutations in the genes that regulate apoptosis ${ }^{(2)}$. A large number of families of genes that regulate apoptosis have been identified in both normal and malignant cells. The bcl-2 gene is the prototype of a newly described family of oncogenes involved in tumorigenesis by blocking apoptosis, or programmed cell death. The proto-oncogene bcl-2 is located on chromosome 18 and encodes for a protein that preserves cells from death by apoptosis, allowing them to survive in G0 phase of the cell cycle even in the absence of essential growth factors ${ }^{(3)}$. Over expression of bcl-2 protein was originally described in follicular Bcell lymphomas bearing the 14; 18 translocation. High levels of bcl-2 protein have also been observed in about $25 \%$ of high grade nonHodgkin's lymphomas, malignant skin tumors, as well in solid tumors such as carcinomas of the lung, prostate, nasopharynx, stomach and colon (4). The present study was undertaken to analyze bcl-2 expression in primary cutaneous malignancies, the aim being to evaluate whether anti-apoptotic mechanisms are alone sufficient for development of these malignancies.

Our study depicted that only three Squamous cell carcinoma samples $(12.5 \%)$ exhibited reactivity with anti-bcl-2. This is in coherence to the study that reported minimal to absent bcl-2 keratinocyte expression in cutaneous squamoproliftrative lesions $(<15 \%)^{(10)}$. A study on arsenic-induced skin cancers reported that out of eight squamous cell carcinoma (SCC) lesions, none of the lesions expressed bcl-2 oncoprotein and hence suggested role of other anti-apoptotic and cellular proliferation linked molecules in squamous cell carcinomas ${ }^{(11)}$. Another study depicted only four cases reactive for bcl-2, depicting a percentage positivity of $18 \%{ }^{(12)}$. Their observation is in close agreement with the results of present study.

Basal cell carcinomas expressed high levels of bcl-2 protein depicting a percentage positivity of $80 \%$. Similar study demonstrated that bcl-2 was expressed homogeneously in all of the ten basal carcinoma lesions included in the study, depicting a percentage positivity of $100 \%$ (11) bcl-2 expression was analyzed in $(67 \%)$ of cases of Basal Cell Carcinoma ${ }^{(6)}$. Another study evaluated the bcl-2 expression and its possible role in primary malignancies of the skin and reported that all of 23 samples of Basal Cell Carcinoma expressed bcl-2 which also indicates that cellular expansion may be in part due to inhibition of programmed cell death ${ }^{(13)}$.

Diffuse intracytoplasmic immunopositivity for bcl-2 protein, sometimes with perinuclear accentuation of staining was observed in neoplastic cells in $100 \%$ of malignant melanomas. High levels of bcl-2 protein was reported in 27 of 29 Malignant melanoma $(93.1 \%)$ and 33 of 35 benign melanocytic nevi $(94.3 \%){ }^{(14)}$. Study reported that sixteen of eighteen Malignant Melanomas expressed bcl-2 (88\%) ${ }^{(13)}$. Another study concluded that the bcl-2 in malignant melanoma may play a role in tumor development by sparing the cells from apoptotic death or through cooperation with other oncogenes ${ }^{(15)}$. Most of the observations in relation to malignant melanoma in the present study are more or less in close agreement with most studies by previous authors. The results of the present study indicate that Basal cell carcinomas and malignant melanomas frequently express the bcl-2 gene product. In contrast majority of Squamous cell carcinomas are negative. The expression of bcl-2 could indicate that the cellular expansion of Basal cell carcinomas and malignant melanomas may be in part due to inhibition of programmed cell death. Intense bcl-2 staining in Basal cell carcinomas reveal an important role for bcl-2 in oncogenesis of these tumors or it may simply reflect derivation of these tumors from cells that normally express 
bcl-2. It may also represent a homeostatic response to high rates of apoptosis noted in Basal cell carcinomas.

The lack of expression of bcl-2 in Squamous cell carcinomas suggests that their neoplastic growth is due to deregulation of alternate oncogenes. Although it is tempting to guess that their neoplastic growth is solely due to an increased rate of cellular proliferation, inhibition of programmed cell death cannot be entirely excluded as there are other genes that regulate apoptosis. Never theless, the consistent lack of expression of bcl-2 in Squamous cell carcinoma contrasts with the staining in the basal cell carcinoma and the basal cell layer. This observation could sugguest that Squamous cell carcinomas may not share the same cell of origin as basal cell carcinoma. The frequent expression of bcl-2 by malignant melanoma is not altogether surprising as bcl-2 expression in resting melanocytes in normal skin has been repeatedly documented.

Bowen's disease showed immunoreactivity with anti-bcl-2, depicting a percentage positivity of $60 \%$. The expression of bcl-2 protein was restricted to the involved lesions and surrounding normal tissue with keratinocytes were bcl-2 negative. It was reported that bcl-2 was expressed in $40 \%$ of the Bowen's disease focally or homogeneously and suggested that expression of bcl-2 in Bowen's disease is related to the phenotype of germinative basal cell ${ }^{(11)}$. Another study analyzed the expression of the bcl-2 protein immunohistochemically in Bowen's disease and reported that seventy-three percent of cases with Bowen's disease showed obvious bcl-2 protein expression $^{(6)}$.

Only 20\% exhibited immunoreactivity for antibcl-2 in Keratoacanthoma in our study. One of the study suggested that the degree and pattern of staining imply a loss of bcl-2 expression with tumor maturity in keratoacanthoma and a possible role in their ultimate involution ${ }^{(16)}$. Similarly bcl2 expression in 5 cases of keratoacanthoma was found to be negative ${ }^{(16)}$. Another study reported minimal to absent keratinocyte bcl-2 expression in keratoacanthomas ${ }^{(10)}$.

Conflict of Interest: The authors declare that there is no conflict of interest.

\section{Acknowledgment}

Authors highly acknowledge the support interms of lab facilities provided by Department of Pathology, MAMC (Maulana Azad Medical College New Delhi). Technical Support provided by Prof. Vinay Kamal, Depart. Of Pathology MAMC New Delhi is highly appreciated.

\section{REFERENCES}

1. National tumor register, Lousiana, U.S.A.

2. Wyllie AH. Apoptosis: Cell death in tissue regulation. Journal of pathology 153:313, 1987.

3. Vaux DL, Cory $\mathrm{S}$, et al. bcl-2 gene promotes haematopoietic cell survival to immortalize cell survival. Nature.1988; 335:440-2.

4. Ngan BY, Chen-Levy Z, et al. Expression in non-Hodgkin's lymphoma of the bcl-2 protein associated with $\mathrm{t}(14 ; 18)$ chromosomal translocation. N Engl J Med. 1988 Jun 23; 318(25):1638-44.

5. Hockenbery D, Nunez G, et al. bcl-2 is an integral inner mitochondria! membrane protein that blocks programmed cell death. Nature. 1990 Nov 22; 348(6299):334-6.

6. Nakagawa K, Yamamura K, Maeda S, Ichihashi M. bcl-2 expression in epidermal keratinocytic diseases. Cancer 1994; 74: 1720-4.

7. Saenz-Santa Maria MC, Reed JA, McNutt $\mathrm{NS}$, et al. Immunohistological expression of bcl-2 in melanomas and intradermal nevi. J Cutan Pathol. 1994 Oct; 21(5):3937.

8. Ramsay JA, From L, Kahn HJ. et al. bcl-2 protein expression in melanocytic neoplasms of the skin. Mod Pathol. 1995 Feb; 8(2):150-4. 
9. Tsujimoto Y, Shimizu S. et al. Role of the mitochondrial membrane permeability transition in cell death. Apoptosis. 2006 Nov 21.

10. Wrone-Smith T, Bergstrom J, Quevedo $\mathrm{ME}$, et al. Differential expression of cell survival and cell cycle regulatory proteins in cutaneous squamoproliferative lesions.J Dermatol Sci. 1999 Jan; 19(1):53-67.

11. Chang $\mathrm{CH}$, Tsai RK, Chen GS, et al. Expression of bcl-2, p53 and $\mathrm{Ki}$ in arsenical skin cancers. J Cutan Pathol.19980ct; 25(9):457-62.

12. Swanson PE, Fitzpatrick MM,Ritter J H, Glusac E J,et al. Immunohistologic differential diagnosis of basal cell carcinoma, squamous cell carcinoma, and trichoepithelioma in small cutaneous biopsy specimens.J Cutan Pathol. 1998 Mar; 25(3):I53-9.

13. Morales-Ducret CR, van de Rijn M, et al. bcl-2 expression in primary malignancies of the skin. Arch Dermatol. 1995 Aug; 131(8):909-12.

14. Cerroni L, Soyer HP, Kerl H. et al. bcl-2 protein expression in cutaneous malignant melanoma and benign melanocytic nevi. Am J Dermatopathol. 1995 Feb; 17(1):711.

15. Van den Oord JJ, Vandeghinste N, De Ley $\mathrm{M}$, et al. bcl-2 expression in human melanocytes and melanocytic tumors. Am J Pathol. 1994 Aug; 145(2):294-300.

16. Sleater JP, Beers BB, Stephens CA, et al. Keratoacanthoma: a deficient squamous cell carcinoma? Study of bcl-2 expression. J Cutan Pathol. 1994 Dec; 21(6):514-9. 